\title{
PRODUCTIVITY OF ROAD FREIGHT TRANSPORT SERVICES IN POLAND AN EU
}

\section{DARIUSZ MILEWSKI}

University of Szczecin, Faculty of Management and Economics of Services, POLAND

e-mail: dariusz.milewski@wzieu.pl

\author{
\begin{tabular}{l|l} 
RECEIVED & 6 November 2018
\end{tabular} \\ ACCEPTED $\quad 3$ December 2018 \\ JEL \\ CLASSIFICATION \\ L20, L91, M20
}

KEYWORDS $\quad$ productivity of transport services, freight transport, performance ofroad haulage

ABSTRACT The paper deals with the problem of the productivity of transportation services in freight road transport. The considerations focus on the market in Poland. It presents the results of calculations made by the author. The goal of it was to identify possible factors of this productivity. Classical measures were used - tkm/vehicle and EUR/vehicle. The main thesis was that the productivity of this sector transport is influenced by external factors (area and GDP of country) and thus independent from transport companies. The relations between this productivity and its factors and observed phenomena seems to be confirmed in case of Poland but surprisingly not on the European level. Because of that the author postulates to conduct further and deeper research.

\section{Introduction}

Productivity is considered as one of the most important factors of economical effectiveness of companies and whole economies. That refers also to the sector of transport, which serve the other branches of economies. The biggest share of the whole transportation systems belongs to the road transport. On this productivity many 
factors have an influence - not only internal - first of all methods of management the transportation processes but also the external and independent from the transport services providers.

The demand for the transport services is variable in time and space and difficult to predict and transportation companies don't have much influence on this demand and have to adjust to it. This demand is the result of the so called transport needs, which in turn result from the external factors - spatial distribution of production and consumption, geographical, social, cultural and demographic factors. The demand for transport services is secondary in relation to the demand for manufactured and transported goods.

According to the opinions of the representatives of the transport and logistics sector efficient management of a transport company and transport processes has limited impact on financial results of these companies. External factors and independent of transport companies are the most important factors. The purposes of such opinions, expressed in professional paper or conferences, is perhaps to draw attention to the problems of the transport society and it is difficult to treat them as objective. Yet to at least to some extent seems to be true.

In fact there are also internal factors have also important impact of productivity. Good organization of transport processes performed for example by freight forwarders. This organization is supported by the so called modern technologies - computer systems, telematics, satellite navigation. The size of a company plays also important role, because bigger companies are usually more productive, what confirms the existence of the scale effect also in transport. Also a proper strategy of a company - e.g. a choice o market on which services are to be provided.

The intention of the Author of this paper was to analyze on the base of available statistical data factors of the productivity of services provided by carriers in freight road transport. The results of this analysis could at least inspire for further and deeper studies.

The author has also used the results of own research work and practical experience in the field of transport and logistics.

\section{Litepature review}

Transport is a very important factor in the productivity of logistics processes. According to some authors, transport costs may account for $15 \%$ of logistics costs, and logistic costs alone may amount to $20 \%$ of process costs in manufacturing enterprises (Rostek, Knosala, 2017, p. 87). Not only costs of transport are important but also quality of transport services which affects economical effectiveness of transport users. This the reason why the largest share in case of integrated logistics and production strategies such as JIT and ECR has road transport, which is characterized by its high flexibility.

The success of enterprises depends on to much extent more and more high productivity and efficiency of the transportation means and also on quality of services, operating costs and high adaptability to a changing environment (Stajniak, Koliński, 2014, pp. 5932-5938).

In general terms, productivity is defined as the relation of anoutput (goods produced, services) to an input (resources consumed) (Piętkowska-Laska, 2015, p. 5319). Similar can be defined the productivity of transportation services in general and especially in the freight road transport. The output in freight transport is traditionally measured first of all by tons and ton-kilometers or sometimes in terms of value (turnover). As input - the volume of production resources measured in terms of personnel, vehicles, infrastructure, rolling stock, information and communication systems (Blanquart, Burmeister, 2009, pp. 135-145) 
The performance of these services depends on the close interrelations with manufacturing systems, logistics management and information and communication systems (Stapleton, 2002, pp. 89-107). That leads to the conclusion, that from one side it depends on the proper management in companies, from the other however that yet from external factors.

In classical literature a service is considered as immaterial, co-produced between user and producer, nonstorable, and non-transportable and heterogeneous (Edgett, Parkinson, 1993, pp. 19-39; Zeithaml, Parasuraman, Berry, 1985, pp. 33-46). They are reasons, for which it is very difficult to effectively manage the processes of production of services and obtaining high level of their productivity.

Similar features characterize transport and logistics services. Yet transport services has its own unique features, which considerable distinguish them from other types of economic activities and production of other services. These features of production of transport services such as immateriality, simultaneity of production and consumption, inability to produce for stock are the reason for the low level of service standardization, which is largely related to the impact of external factors. This means that transport of the same load at the same distance, using the same mode of transport may have different qualitative or cost effects. The reasons are different weather conditions, social and political factors, the possibility to find a return cargo from a given location.

The transport services are performed in space, what has serious consequences for the productivity and also for the productivity indicators. The performance of the transport services cannot be assessed with use of general indicators like for example number of orders realized by a transport operator. Very important factor is a vehicle mileage and utilization of a vehicle in both directions. Also a size of a consignment and capacity utilization of a vehicle is important. The benefits of scale is also important factor of the economic efficiency in transport.

Various productivity indicators in transport have been developed and the choice of them depends on the purpose of their application. They can be very detailed and reflect the factors affecting this productivity (Stajniak, Koliński, 2014, pp. 5932-5938). Productivity measures can be transport time per transport order, utilization rate of transport means, efficiency of means of transport, number of kilometers per 1 means of transport, number of kilometers per driver, average repair time (Barcik, Jakubiec, 2010, p. 6-7).This diversity has its justification because it allows research in various areas, various factors of productivity and take into account the diverse impact of logistics processes and services, including transport on the financial results of enterprises.

Analysis performed by Kozłowska using the DEA method (Kozłowska, 2014, pp. 309-312) showed that in the freight transport sector companies are characterized by rather low technical efficiency of operations. The author also pointed out that in the transport sector it is difficult to control the effects of the operation (in the form of number of orders or revenues), which often depends on external factors (economic situation in the country or in the world).

\section{Productivity of road haulage transport services in Poland}

The analysis of the productivity in the Polish road haulage has been conducted by the author on the base of available data of the Polish Central Statistical Office.

Since 2000 the Polish Economy has been constantly growing despite economical crisis including the last global crisis, which started in 2008 (Table 1 and Figures 1 and 2). Very important factor of this growth was the accession of Poland to EU, which opened new possibilities for the Polish transport services providers. Opening borders and eliminating customs clearances improved the turnover of transport means, what resulted in better productivity but also considerable reduction freight rates in some cases. 
Table 1. Perfomance in road transport in Poland

\begin{tabular}{lrrrrrrrrr}
\hline \multicolumn{1}{c}{ Years } & 2000 & 2002 & 2004 & 2006 & 2008 & 2010 & 2012 & 2014 & 2016 \\
\hline Transport of goods (thousand tones) & 1,007 & 931 & 957 & 1,114 & 1,339 & 1,491 & 1,493 & 1,548 & 1,547 \\
Transport performance (100 million tkm) & 750 & 803 & 1,105 & 1,365 & 1,742 & 2,142 & 2,333 & 2,629 & 3,036 \\
GDP mld PLN & 747 & 811 & 933 & 1,070 & 1,286 & 1,445 & 1,629 & 1,719 & 1,858 \\
\hline
\end{tabular}

Source: own calculations based on data from: GUS (2018).

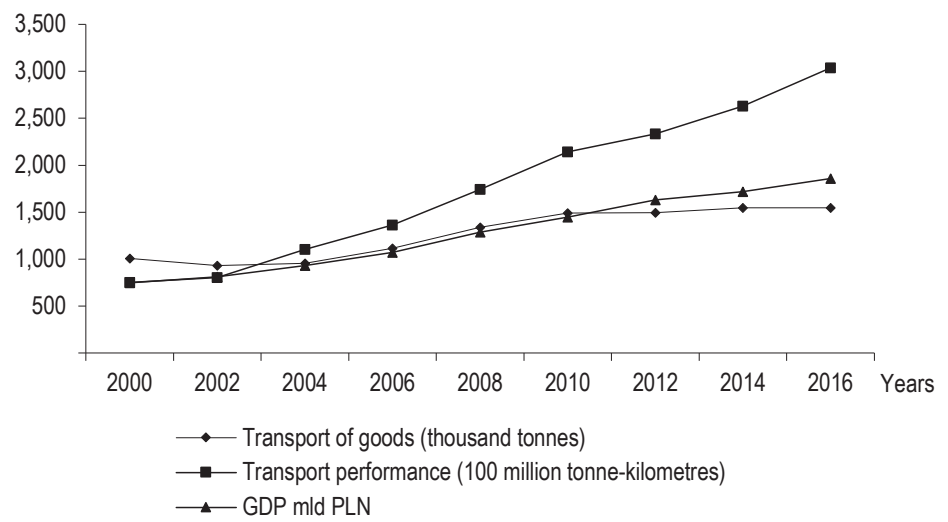

Figule 1. Perfomance of road transport in Poland

Source: own calculations based on data from GUS (2018).

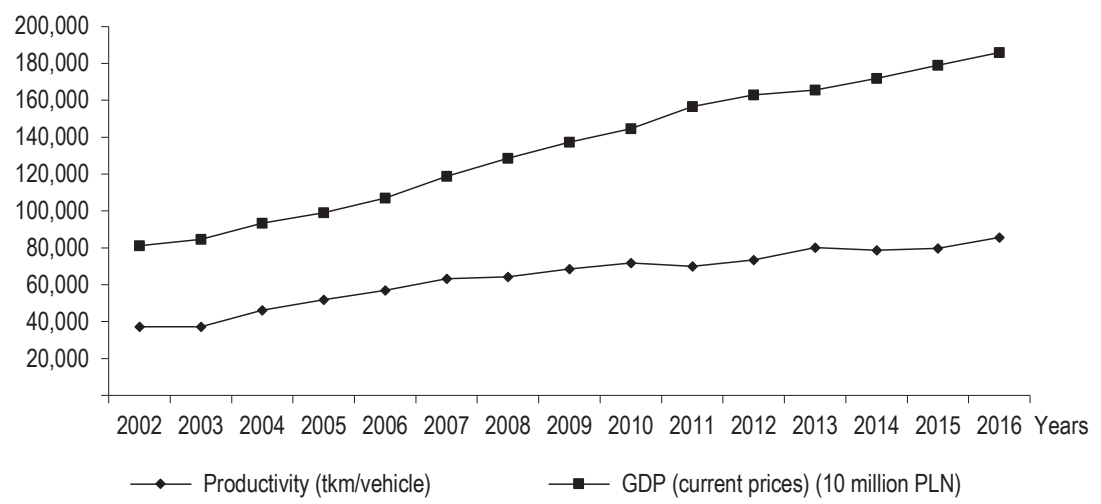

Figure 2. Productivity of road haulage and GDP in Poland

Source: own calculations based on data from: GUS (2018).

Also the average distance of travel has been increased but not so much (from $75 \mathrm{~km}$ in 2000 year to $196 \mathrm{~km}$ in 2016).That can explain more bigger increase of performance measured by tkm than by tones as absolute values 
and calculated per 1 vehicle (Table 2 and Figure 3). Anyway an increase of a distance also leads to the reduction of prices for transport services - on longer distances freight rates are usually lower. On the other hand however there are then greater possibilities for finding return loads.

Table 2. Productivity of road haulage in Poland

\begin{tabular}{lcccccccc}
\hline \multicolumn{1}{c}{ Years } & 2009 & 2010 & 2011 & 2012 & 2013 & 2014 & 2015 & 2016 \\
\hline Goods Transport Revenues (100 thous. PLN) & 558 & 598 & 647 & 719 & 739 & 831 & 887 & 950 \\
Registered road vehicles (100 pcs.) & 280 & 298 & 313 & 318 & 324 & 334 & 343 & 354 \\
Average distance (km) & 134 & 144 & 137 & 156 & 167 & 170 & 181 & 196 \\
Road tractors (thousands) & 201 & 215 & 239 & 257 & 280 & 303 & 330 & 362 \\
Productivity (tonnes/vehicle) & 509 & 500 & 510 & 470 & 479 & 463 & 439 & 437 \\
Productivity (100 tkm/vehicle) & 685 & 718 & 699 & 734 & 801 & 787 & 797 & 857 \\
Productivity (100 thous. PLN/vehicle) & 199 & 201 & 207 & 226 & 228 & 249 & 259 & 268 \\
\hline
\end{tabular}

Source: own calculations based on data from: GUS (2018).

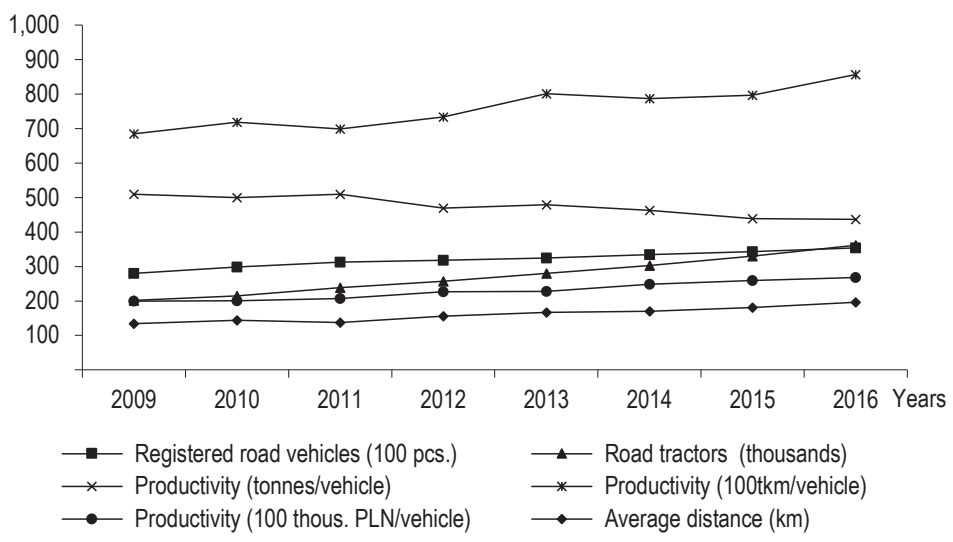

Figure 3. Productivity of road haulage in Poland

Source: own calculations based on data from: GUS (2018).

Although number of tones per vehicle has been falling, yet the economical efficiency measured by PLN/ vehicle has increased (Figure 3). That could mean that despite smaller consignments shipped by transportation users Polish haulers can make bigger profits. In this context it is puzzling, that the number of road tractors is increasing faster than the number of road vehicles. That means, that bigger vehicles are relatively less utilized since an average load is decreasing.

The productivity of the market of freight road transport in Poland and possible relations between this productivity and its factors seems surprisingly different from the European markets.

First of all in EU the productivity measured as tkm per vehicle has been falling for many years (Figure 4). The productivity measured as EUR per vehicles is relatively stable, what can indicate, that despite worse utilization of vehicles, the transportation companies earn more money. The simplest explanation is that market is shifting 
towards more sophisticated but more profitable services. That hypothesis could be proved by the structure of transportation fleet of European service providers in which lighter vehicles dominate (Figure 5). This is puzzling, that middle ones have the least share. Perhaps that could be explained, that companies use integrated systems of delivering of goods, in which cargoes are collected by smaller vehicles and transported as consolidated cargo in the heaviest trucks.

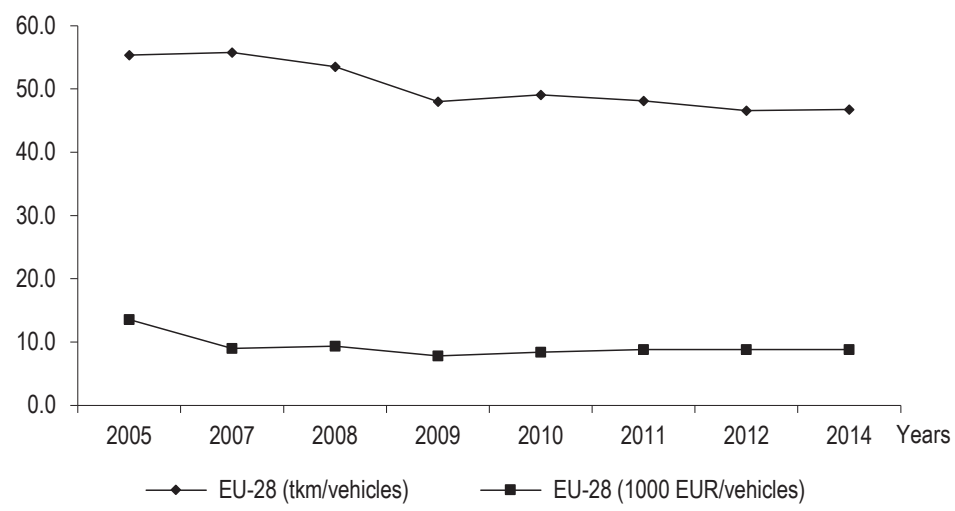

Figure 4. Productivity of road haulage in EU

Source: own calculations based on data from: Eurostat (2018).

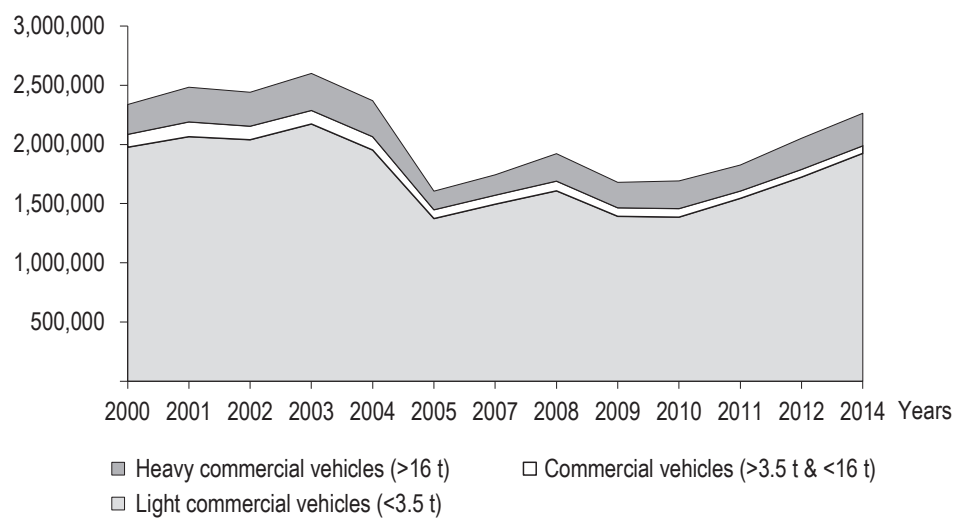

Figure 5. Structure of loading capacity of goods vehicles in EU

Source: Eurostat (2018).

In order to find out if economical conditions (external factors) influence the productivity, two correlations between two productivity indicators have been measured: between transport performance measured as tkm/ vehicle and EUR/vehicle and an area of a country and its GDP. On the base of the simulations conducted by author it seems, that there are no strict relations between them (Figures 6 and 7). Although among the most productive we 


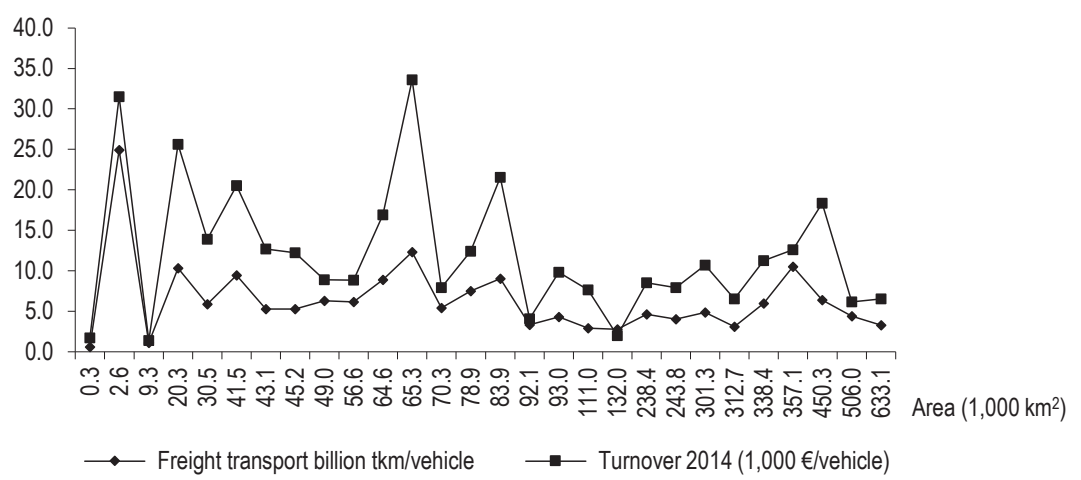

Figure 6 . Productivity of road haulage in EU

Source: own calculations based on data from: Eurostat (2018).

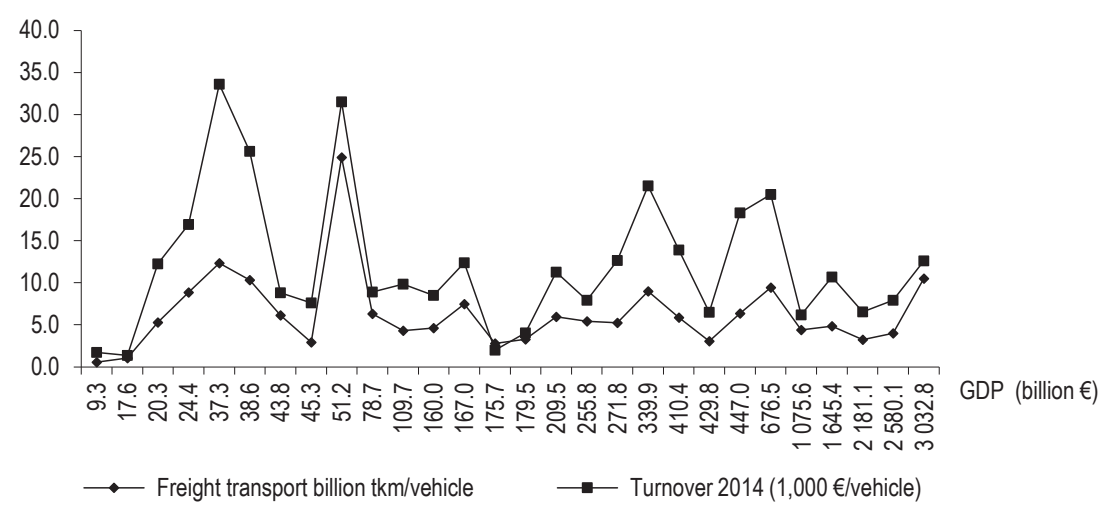

Figure 7. Productivity of road haulage in EU

Source: own calculations based on data from: Eurostat (2018).

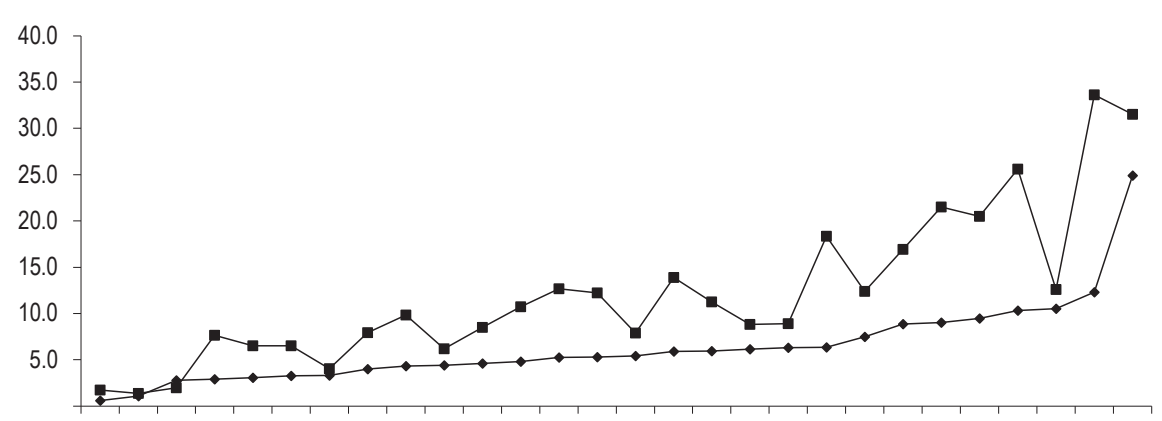

MT CY EL BG PL FR PT UK HU ES RO IT DK EE IE BE FI HR SK SE CZ LV AT NL SI DE LT LU

$\longrightarrow$ Freight transport billion $\mathrm{tkm} /$ vehicle

$\longrightarrow$ Turnover $2014(1,000 € /$ vehicle)

Figure 8. Productivity of road haulage in EU

Source: own calculations based on data from: Eurostat (2018). 
can find Luxembourg, Austria, Germany and Netherlands but also smaller countries and not the richest ones like Lithuania and Slovenia (Figure 8). From these results again we can see, that the relations between these measures of productivity are not linear - the productivity measured in tkm/vehicle doesn't always results in higher turnover per vehicle.

\section{Conclusions}

To some extent the statistical data concerning freight road transport seem to confirm the theoretical, classical theory of transport economics but not in all European economies.

The greatest surprise is aroused by large differences in productivity between Poland and the entire European Union. The differences concern not only the level of productivity but also relations between productivity and its external factors. It difficult to believe, that Poland is unique country although according to the some research the performance of the Polish haulers is very high in comparison to other European countries (Eurostat, 2018).

It is difficult at this stage of research to find answer to all questions and further and deeper research is required. The adequacy of statistical data can be doubtful. For example in case of Poland some data are collected from enterprises employing more than 9 persons, what significantly limits the scope of research, because smaller haulers dominate in the freight road transport.

\section{References}

Barcik, R., Jakubiec, M. (2010). Zarządzanie kosztami w transporcie. Logistyka, 4 (CD-CD), 6-7.

Blanquart, C., Burmeister, A. (2009). Evaluating the performance of freight transport: a service approach. European Transport Research Review, 3 (1), 135-145.

Edgett, S., Parkinson, S. (1993). Marketing for Services Industries, A Review. The Services Industries Journal, 13, 19-39.

Eurostat (2018). National statistics, United Nations Economic Commission for Europe. Retrieved from: http://ec.europa.eu/eurostat/ statistics.

GUS (2018). Transport. Wyniki Działalności. Years: 2000-2017.

Kozłowska, J. (2014). Zastosowanie metody DEA w analizie efektywności działania przedsiębiorstw usługowych. Zeszyty Naukowe Politechniki Śląskiej. Organizacja i Zarządzanie, 73, 305-317.

Piętkowska-Laska, R. (2015). Produktywność systemów logistycznych. Ujęcie teoretyczno-praktyczne. Logistyka, 4, 5315-5322.

Rostek, M., Knosala, R. (2017). Ocena produktywności logistyki przedsiębiorstwa z wykorzystaniem pośrednich mierników produktywności. In: R. Knosala (ed.), Innowacje w zarządzaniu i inżynierii produkcji (p. 87). Tom II. Opole: Wydawnictwo PTZP.

Stajniak, M., Koliński, A. (2014). Analiza efektywności procesów transportowych w łańcuchu dostaw. Logistyka, 3, 5932-5938.

Stapleton, D. (2002). Measuring logistics performance using the strategic profit model. International Jorunal of Logistics Management, 13 (1), 89-107.

Zeithaml, A.V, Parasuraman, A., Berry, L.L. (1985). Problems and Strategies in Service Marketing, Journal of Marketing, 2 (49), 33-46.

Cite this article as: Milewski, D. (2018). Productivity of road freight transport services in Poland an EU. European Journal of Service Management, 4 (28/1), 215-222. DOI: 10.18276/ejsm.2018.28/1-27. 